\title{
Technical and operating problems yielded from setting up the optimum value of geometric compression ratio in piston engines
}

\begin{abstract}
The article discusses the problem of choosing the optimal compression ratio value in internal combustion engines at their design phase, according to today's development trends toward high economy and ecology of road transportation and the divers' expectations in vehicle use and performance. Because the variable compression ratio technology VCR is not yet developed well enough to be implemented into the mass production of engines in the near future, the choice of compression ratio value is always a serious task for constructors to find a compromise between the functional engine properties, operational characteristics, engine efficiency, the powertrain design complexity, and finally the exhaust emission level. Therefore, the paper examines the impact of the compression ratio on the combustion engine parameters mentioned above and presents some innovative designs, where the settings of the compression ratio value beyond the conventional range is connected with using additional solutions in design structure and control systems, with modifications corresponding to the working process in these engines.
\end{abstract}

Key words: compression ratio, variable compression ratio engine, $V C R$

\section{Uwarunkowania techniczne i eksploatacyjne związane z wyborem optymalnej wartości geometrycznego stopnia sprężania w silnikach tlokowych}

\begin{abstract}
W artykule omówiono problem wyboru optymalnej wartości stopnia sprężania przy konstruowaniu silników spalinowych, zgodnie z trendami rozwojowymi w zakresie spetnienia wskaźników ekonomiki i ekologii transportu drogowego oraz ze współczesnymi oczekiwaniami użytkowników pojazdów w zakresie ich osiagów i eksploatacji. Ponieważ technologia zmiennego stopnia sprężania VCR (ang. Variable Compression Ratio) nie jest jeszcze na tyle zaawansowana, aby można było oczekiwać w najbliższym czasie jej wdrożenia do produkcji seryjnej, wybór wartości stopnia sprężania jest dla konstruktorów zawsze zadaniem znalezienia kompromisu pomiędzy założonymi parametrami użytkowymi, cechami eksploatacyjnymi, sprawnościa silnika, złożonościa konstrukcji i poziomem emisji szkodliwych składników spalin. $W$ artykule przedstawiono zatem przeanalizowany wpływ wartości stopnia sprężania na wymienione wyżej parametry silników spalinowych oraz podano przykłady innowacyjnych konstrukcji, w których ustalenie wartości stopnia sprężania poza konwencjonalnym zakresem uwarunkowane jest zastosowaniem dodatkowych rozwiąań konstrukcyjnych i systemów sterujacych, odpowiednio modyfikujacych przebieg procesu roboczego w tych silnikach.
\end{abstract}

Słowa kluczowe: stopień sprężania, silnik o zmiennym stopniu sprężania, VCR

\section{Introduction}

Current and future development of internal combustion engines is conditioned primarily by the ecological and economic issues related to transportation that are clearly reflected by the limits of exhaust gas emission including carbon monoxide $\mathrm{CO}$, hydrocarbons $\mathrm{HC}$, nitric oxides $\mathrm{NO}_{x}$, particulates $\mathrm{PM}$, smoke, and carbon dioxide $\mathrm{CO}_{2}$. All the emissions, particularly $\mathrm{CO}_{2}$, are directly related to the amount of fuel consumed by the vehicle. Although carbon dioxide is not considered a toxic gas but many believes it plays a significant role in generating the greenhouse effect. Therefore, a permanent trend is to strive to further increasing the efficiency of propulsion systems for automotive vehicles and progressive substitution of fossil fuels with renewable energy sources.

The primary piston engine design parameter affecting the previously mentioned operational indicators is the compression ratio $\varepsilon$. It is defined as the ratio of minimum

\section{Wprowadzenie}

Obecny i przyszły rozwój silników spalinowych uwarunkowany jest przede wszystkim względami ekologicznymi i ekonomiką transportu. Wymagania w tym zakresie wyraźnie odzwierciedlają limity emisji składników spalin, tj. tlenku węgla $\mathrm{CO}$, węglowodorów $\mathrm{HC}$, tlenków azotu $\mathrm{NO}_{\text {, }}$ cząstek stałych PM, zadymienia, a także dwutlenku węgla $\mathrm{CO}_{2}$, którego emisja pozostaje w bezpośredniej relacji z ilością zużywanego przez pojazd paliwa. Dwutlenek węgla wprawdzie nie jest gazem toksycznym, lecz sądzi się, że odgrywa on znaczącą rolę w generowaniu efektu cieplarnianego. $Z$ tego względu stałym trendem jest dążenie do dalszego podniesienia sprawności układów napędowych pojazdów samochodowych oraz sukcesywne zastępowanie paliw pochodzenia kopalnego paliwami odnawialnymi.

W silnikach tłokowych podstawowym parametrem konstrukcyjnym, wpływającym na wcześniej wspomniane wskaźniki pracy, jest stopień sprężania $\varepsilon$. Określony jest on 
combustion chamber volume $\mathrm{V}_{\min }$ at top dead center (TDC) piston position and the maximum volume of combustion chamber $\mathrm{V}_{\text {max }}$, at the bottom dead center (BDC) piston position. For engines currently manufactured, this parameter is structurally set fixed but not at the value ensuring optimum efficiency, especially for wide range of speeds and loads at which traction motors operate. Due to high complexity of the phenomena involved in the entire engine work cycle, the choice of compression ratio value that design engineers have to make together with many other decisions on structural and regulation parameters of the new engine is the result of a multifaceted compromise between expected engine performance and other operational factors, mainly the emission of harmful exhaust components. A brief analysis of the compression ratio values for mass-produced engines, both medium- and high-speed ones, shows that they are chosen from the range of 9.0 to 12.0 (for spark ignition engines) and from 16.0 to 21.0 (for compression-ignition engines). The main constraints for setting the compression ratio at lower limits is the decrease in total engine efficiency below an acceptable level, and for compression-ignition engines also the deterioration of self-ignition stability of the injected fuel and difficulties with cold start. Instead, the constraints for setting the compression ratio at upper limits is intensification of the knocking in spark ignition engines and increasing dynamic loads of the crankshaft and the cylinder group mechanisms in compression-ignition engines.

As a result of efforts towards avoiding unfavorable design compromises in modern reciprocating engines, a few years

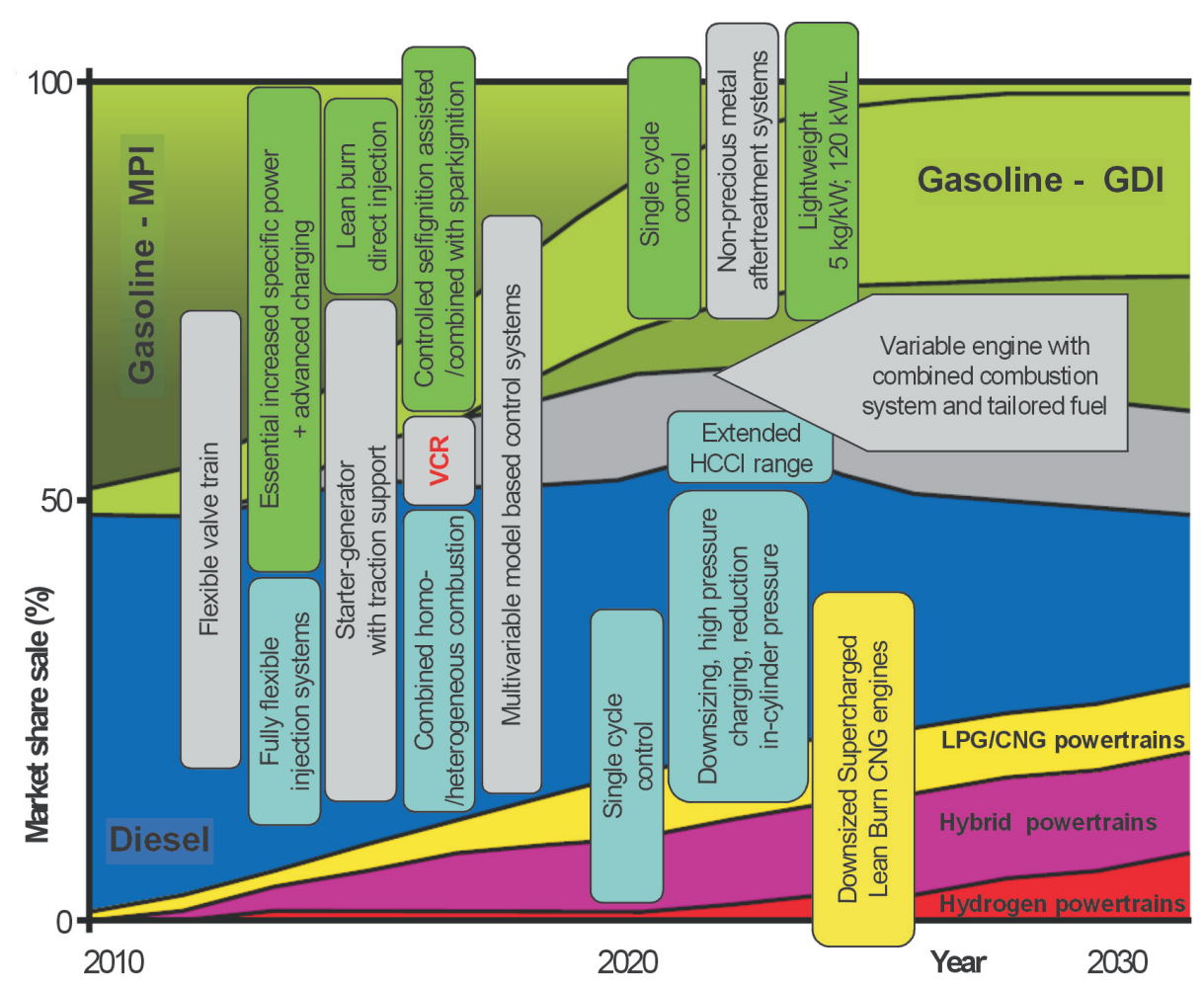

Fig. 1. The forecasts for the development and market share of chosen advanced technologies in automotive combustion powertrains according to [2]

Rys. 1. Prognozy w zakresie rozwoju i udziału wybranych zaawansowanych technologii w spalinowych źródłach napędu pojazdów samochodowych wg [2] przez stosunek minimalnej objętości komory spalania $\mathrm{V}_{\text {min }}$ w zwrocie zewnętrznym (ZZ) tłoka, lub inaczej - górnym martwym położeniu tłoka (GMP), do maksymalnej objętości przestrzeni nadtłokowej $\mathrm{V}_{\text {max }}$ odpowiednio w zwrocie wewnętrznym (ZW), tj. w dolnym martwym położeniu tłoka (DMP). W silnikach obecnie stosowanych w produkcji seryjnej parametr ten jest ustalony konstrukcyjnie na stałe, co nie jest rozwiązaniem zapewniającym optymalną efektywność silnika, zwłaszcza w zmiennych warunkach prędkości i obciążenia, w jakich operują w szczególności silniki trakcyjne. Złożoność zjawisk w całym cyklu roboczym silnika powoduje, że dobór przez konstruktora wartości stopnia sprężania, jak również wielu innych parametrów konstrukcyjnych i regulacyjnych silnika, jest wynikiem określonego kompromisu pomiędzy osiągami silnika a innymi wskaźnikami pracy, przede wszystkim emisją szkodliwych składników spalin. Pobieżna analiza wartości stopnia sprężania w seryjnych silnikach średnio- i szybkoobrotowych wskazuje, że mieszczą się one przeważnie w zakresie od 9,0 do 12 (dla silników z zapłonem iskrowym) oraz od 16 do 21 (dla silników z zapłonem samoczynnym). Podstawowymi ograniczeniami w ustaleniu granicznych dolnych wartości stopnia sprężania jest związany z tym spadek sprawności ogólnej silnika poza akceptowalny poziom, a dla silników z zapłonem samoczynnym również pogorszenie pewności samozapłonu dawki paliwa i procesu rozruchu. Natomiast ograniczeniami "z góry" jest, w przypadku silników z zapłonem iskrowym, nasilenie się zjawiska spalania stukowego, a w odniesieniu do silników z zapłonem samoczynnym również wzrost obciążeń dynamicznych układu $\mathrm{T}-\mathrm{P}-\mathrm{C}$ (tłok-pierścienie-cylinder).

W wyniku dążeń do uniknięcia niekorzystnych kompromisów konstrukcyjnych we współczesnych silnikach tłokowych, kilka lat temu pojawiła się koncepcja, będąca jedną z bardziej zaawansowanych dróg rozwoju silników spalinowych, a odpowiadająca wspomnianym wyżej kierunkom poprawy ich ekologii i efektywności energetycznej, m.in. przez umożliwienie szerszego wykorzystania paliw alternatywnych lub niskotemperaturowych procesów spalania [14]. Chodzi mianowicie o konstrukcje silników, w których stopień sprężania jest parametrem regulacyjnym i może być zmieniany bezstopniowo w szerokim zakresie i stosunkowo krótkim czasie. Technologia ta określana jest mianem VCR (ang. Variable Compression Ratio - zmienny stopień sprę- 
ago a concept has been proposed that is one of the more advanced development paths for combustion engines. It corresponds to the above-mentioned directions for improving environmental impact and energy efficiency of the engines by, among others, allowing wider use of alternative fuels or low-temperature combustion processes [14]. Namely, there are engine designs where the compression ratio is a regulated parameter and can be changed continuously over a wide range and in a relatively short time. This technology is called VCR - Variable Compression Ratio. Works on the development of this type of power drives are conducted by a few research and development centers in the world $[3,9]$, including the authors' team $[12,13]$. While the idea of VCR engines shows a certain complexity of construction and technology and can cause some operational problems, it is expected $[2,10]$, that it could become the standard design for reciprocating engines in the near future, mainly due to the well-established constraints of fixed compression ratio engines (Fig. 1).

\section{The compression ratio as a parameter shaping the performance and operating processes in internal combustion engines}

The compression ratio is a value which heavily influences the thermodynamic parameters in the combustion chamber at the end of the compression stroke, as well as the further course of the combustion process. Increasing the compression ratio decreases specific fuel consumption and increases engine power. This is the result of increased theoretical efficiency of cycle $\eta_{\mathrm{t}}$, which may be expressed mathematically in the simplest form for the Otto cycle (Eq. 1):

$$
\eta_{\mathrm{t}}=1-1 /\left(\varepsilon^{\mathrm{K}-1}\right)
$$

where: $\eta_{\mathrm{t}}-$ Otto cycle theoretical efficiency, $\varepsilon-$ compression ratio, $\kappa$ - polytropic index.

However, the freely increasing the engine efficiency this way is limited, due to the structural and durability constraints as well as the unfavorable changes to the fuel combustion process that appear in spark-ignition engines with compression ratio raised above the permissible limit. In compression ignition engines it is also not possible to increase the compression ratio freely; too high value causes excessive mechanical losses that are greater than the profit resulting from improved overall engine efficiency.

To choose an appropriate compression ratio value many factors must be taken into account. Among them, the most important are:

- octane/cetane number of fuel,

- the material that the piston and piston head are made of,

- combustion chamber design,

- harmful pollutant emissions.

In diesel engines the prerequisite to ignite the fuel injected into the combustion chamber is high pressure and temperature of the cylinder charge at the end of the com- żania). Prace nad tego typu jednostkami napędowymi są prowadzone przez nieliczne ośrodki badawczo-rozwojowe na świecie [3, 9], w tym przez zespół autorów publikacji $[12,13]$. Pomimo tego, że idea silników o zmiennym stopniu sprężania VCR wiąże się z pewnym skomplikowaniem konstrukcyjno-technologicznym oraz problemami eksploatacyjnymi, z uwagi na ograniczenia silników o stałym stopniu sprężania, ocenia się $[2,10]$, że może stać się ona w niedalekiej przyszłości standardem konstrukcyjnym w silnikach tłokowych (rys. 1).

\section{Stopień sprężania jako parametr determinujący właściwości eksploatacyjne i przebieg procesów roboczych silników spalinowych}

Stopień sprężania jest wielkością, od której zależą w zasadniczej mierze parametry termodynamiczne ładunku w cylindrze pod koniec suwu sprężania oraz dalszy przebieg procesu spalania. Wraz ze wzrostem stopnia sprężania maleje jednostkowe zużycie paliwa i wzrasta moc silnika. Jest to skutkiem wzrostu sprawności teoretycznej obiegu $\eta_{\mathrm{t}}$, którą można wyrazić zależnością matematyczną, przedstawioną w najprostszej postaci dla obiegu Otto równaniem (1): gdzie: $\eta_{\mathrm{t}}$ - sprawność teoretyczna obiegu Otto, $\varepsilon-$ stopień sprężania, $\kappa$ - wykładnik politropy.

Jednak możliwości dowolnego zwiększania tym sposobem sprawności silników są ograniczone ze względów konstrukcyjnych, wytrzymałościowych oraz przez niekorzystny przebieg spalania paliw w silnikach z zapłonem iskrowym o podniesionym ponad dopuszczalną granicę stopniu sprężania. W silnikach z zapłonem samoczynnym nie jest również możliwe dowolne zwiększanie stopnia sprężania; zbyt wysoka jego wartość powoduje nadmierne straty mechaniczne, które są większe niż zysk wynikający z poprawy sprawności ogólnej silnika.

Aby dobrać odpowiednią wartość stopnia sprężania, należy wziąć pod uwagę wiele czynników. Do najważniejszych należą:

- liczba oktanowa/cetanowa użytego paliwa,

- materiał głowicy i tłoka,

- konstrukcja komory spalania,

- emisja szkodliwych składników spalin.

W silnikach o zapłonie samoczynnym warunkiem koniecznym do zapłonu paliwa wtryśniętego do komory spalania jest odpowiednio wysokie ciśnienie i wysoka temperatura ładunku cylindra w końcu suwu sprężania. Najtrudniejsze warunki do osiągnięcia odpowiednich wartości tych parametrów istnieją podczas zimnego rozruchu silnika. Na ciśnienie sprężania, oprócz stopnia sprężania, pewien wpływ ma również prędkość obrotowa rozruchu silnika; stąd istotna jest też sprawność układu rozruchowego silnika.

W rezultacie bazowania na teorii silników tłokowych, znana jest zależność termodynamiczna na temperaturę czynnika roboczego w końcu suwu sprężania $\mathrm{T}_{2} \mathrm{w}$ funkcji stopnia sprężania, o postaci (2), gdzie: $\mathrm{T}_{1}$ - temperatura ładunku cylindra na początku suwu sprężania, $\mathrm{T}_{2}$ - tempe- 
pression stroke. The most difficult conditions to achieve appropriate values for these parameters exist during engine cold start. Here, the end-of-stroke compression pressure is affected generally by the compression ratio and motor starting speed; hence the effectiveness of the engine starter system is also important.

Based on the theory of piston engines, there is a known thermodynamic dependence of working charge temperature at the end of the compression stroke $T_{2}$ as a function of compression ratio in the form:

$$
\mathrm{T}_{2}=\mathrm{T}_{1} \varepsilon^{\mathrm{m}_{1}-1}
$$

where: $T_{1}$ - in-cylinder temperature at the beginning of compression stroke, $\mathrm{T}_{2}$ - in-cylinder temperature at the end of compression stroke, $\varepsilon$ - compression ratio, $\mathrm{m}_{1}$ - average polytropic index at compression stroke.

Experimental studies on the effect of the compression ratio on the diesel engine starting process were performed by Abramek [1]. The author gives, among others, the relationship between the temperature in the combustion chamber at the end of the compression stroke and the time of cold starting of the engine as a function of compression ratio. According to the expectations based on the previously cited theoretical equations, the temperature of cylinder charge increases as the compression ratio is increased (Fig. 2), while the time required to start-up the cold engine decreases (Fig. 3).

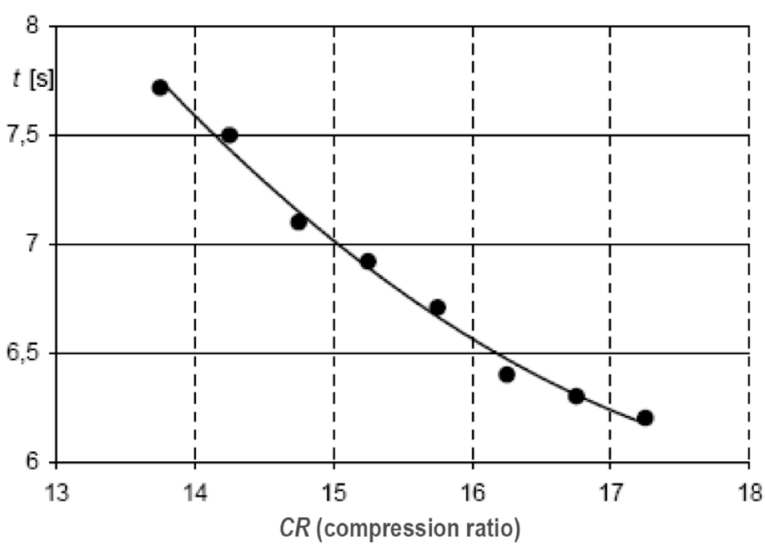

Fig. 3. Effect of compression ratio on the time required for start-up the cold diesel engine [1]

Rys. 3. Wplyw stopnia sprężania na czas zimnego rozruchu silnika z zaptonem samoczynnym [1]

Going further, an equally important effect on the process of fuel injection and atomization in the combustion chamber is the effect of the compression ratio, in particular the compression pressure. Appropriate relationships and experimental results are given by Zablocki in his fundamental work [15]. These interactions have implications for the subsequent stages of the operating cycle, and one can say that in light of the current technical accounts and legislations in the development of internal combustion engines, the most significant is the effect of compression ratura ładunku cylindra w końcu suwu sprężania, $\varepsilon$ - stopień sprężania, $\mathrm{m}_{1}$ - średni wykładnik politropy sprężania.

Badania doświadczalne nad wpływem wartości stopnia sprężania na proces rozruchu silnika z zapłonem samoczynnym prowadził Abramek [1]. Autor podał m.in. zależność temperatury ładunku w cylindrze w końcu suwu sprężania oraz czasu zimnego rozruchu silnika w funkcji stopnia sprężania. Zgodnie z przewidywaniami na podstawie wcześniej przytoczonych zależności teoretycznych, wraz ze wzrostem stopnia sprężania rośnie temperatura ładunku w cylindrze (rys. 2), maleje natomiast czas wymagany do rozruchu zimnego silnika (rys. 3).

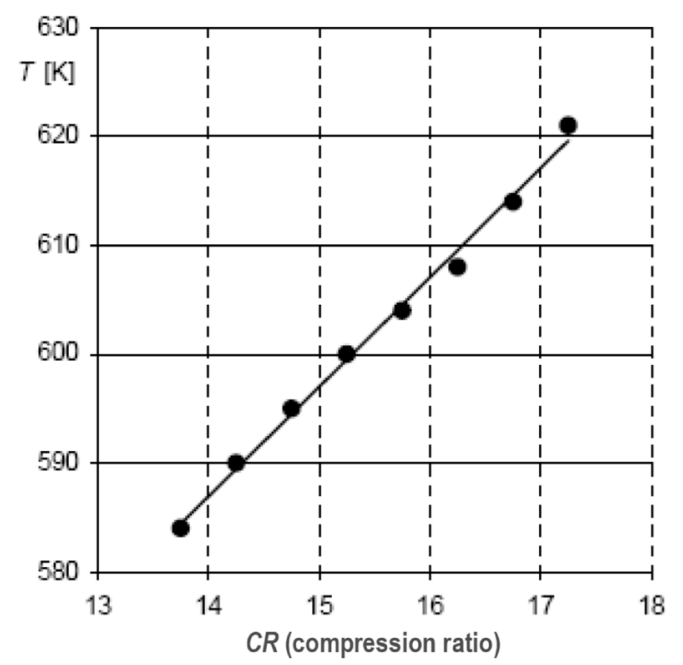

Fig. 2. Effect of the compression ratio on the in-cylinder temperature at the end of the compression stroke [1]

Rys. 2. Wplyw stopnia sprężania na temperaturę ładunku w cylindrze w końcu suwu sprężania [1]

Także istotny jest wpływ stopnia sprężania, a w szczególności ciśnienia sprężania na przebieg procesu wtrysku i rozpylenia paliwa w komorze spalania (odpowiednie zależności i wyniki badań doświadczalnych podaje w swej fundamentalnej pracy Zabłocki [15]). Oddziaływania te mają implikacje dla kolejnych etapów cyklu roboczego i można powiedzieć, że w świetle obecnych uwarunkowań technicznych i prawnych w rozwoju silników spalinowych najbardziej znaczącym jest wpływ wartości stopnia sprężania na przebieg i efekty procesu spalania, tj. parametry użytkowe, ekonomikę pracy i emisję szkodliwych składników spalin. Jeśli chodzi o dwa pierwsze wymienione efektów, to korzystne jest stosowanie wyższych wartości stopnia sprężania z uwagi na towarzyszący temu wzrost sprawności obiegu, a w rezultacie wzrost średniego ciśnienia indykowanego. Wskazują na to, prócz jałowych zależności teoretycznych, również wyniki przeprowadzonych symulacji (rys. 4) z użyciem pakietu Diesel-RK [6, 7] dla prototypowego silnika o zmiennym stopniu sprężania VCR, wg autorskiego $[12,13]$ projektu i konstrukcji, pracującego w trybie zapłonu samoczynnego.

Przeprowadzone obliczenia w zakresie emisyjności spalin wskazują jednak na kontradykcyjny efekt stopnia 
ratio on the course and effects of the combustion process, i.e. output performances, operation efficiency and harmful emissions. As for the first two of these effects, it is preferred to use higher values of the compression ratio because of the increased cycle efficiency resulting in an increased mean indicated pressure. Apart from clean theoretical dependencies this is also proven by the results of the simulations (Fig. 4) using Diesel-RK package [6,7] for a prototype engine of variable compression ratio VCR according to the authors' own design and construction that operates as the compression-ignition engine $[12,13]$.

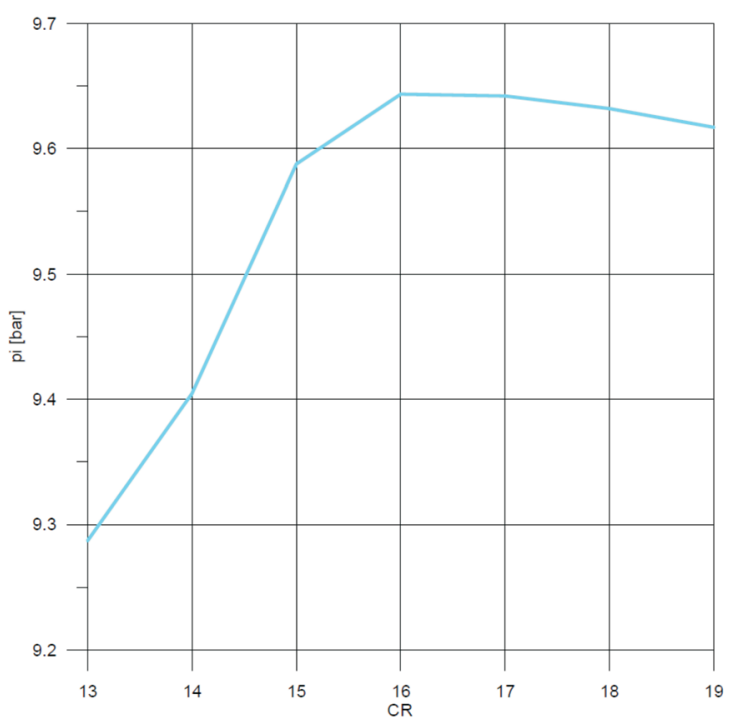

Fig. 4. Effect of compression ratio on mean indicated pressure for variable compression ratio VCR engine

Rys. 4. Wplyw stopnia sprężania na wartość średniego ciśnienia indykowanego w silniku o zmiennym stopniu sprężania VCR

However, the calculations for exhaust gas emission show the contradictions between the compression ratio and the analyzed indicators. This is mostly evident for changes in particulate PM (Fig. 5) and nitrogen oxides $\mathrm{NO}_{\mathrm{x}}$ (Fig. 6) emissions.

From analysis of the presented curves it can be concluded that finding an appropriate constructional setting of compression ratio value is not an obvious problem. On the one hand, to follow high energy conversion efficiency and positive environmental effects on particulate matter emissions, the optimum compression ratio should be set around the value of 16.0. Such values are generally standard sets for modern compression-ignition engines; it guarantees proper engine operating characteristics, for example the easy and reliable engine start-up in low temperatures. However, considering the significant problem of nitrogen oxide emissions, it would be better to lower the values of the compression ratio, even below 14.0, which, as the further discussion will show, involves the use of additional advanced systems that ensure a stable operation of the engine, especially during the warm-up phase. sprężania w obszarze analizowanych wskaźników. Najbardziej widoczne jest to w zestawieniu przebiegu zmian emisji cząstek stałych PM (rys. 5) i tlenków azotu $\mathrm{NO}_{x}$ (rys. 6).

Analizując przedstawione przebiegi, można stwierdzić, że ustalenie konstrukcyjnej wartości stopnia sprężania

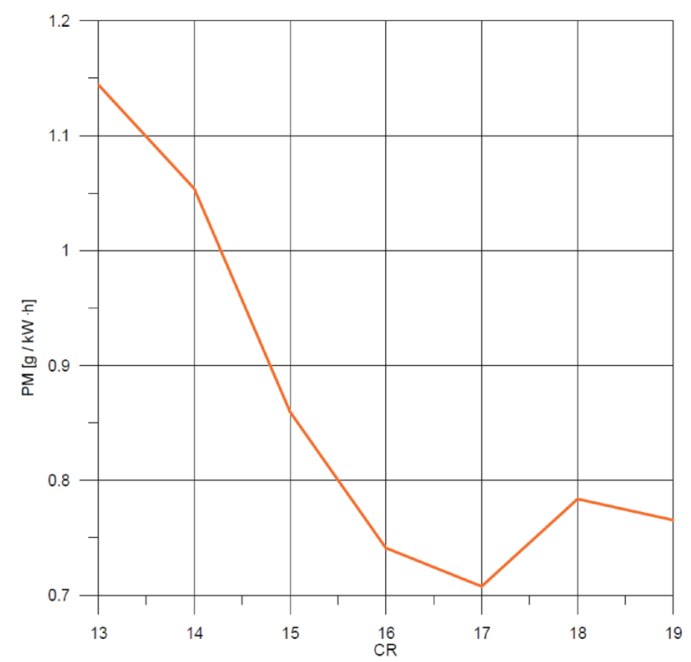

Fig. 5. Effect of compression ratio on particulate matter PM specific emission for variable compression ratio VCR engine

Rys. 5. Wplyw stopnia sprężania na emisję jednostkową cząstek stałych $P M w$ silniku o zmiennym stopniu sprężania VCR

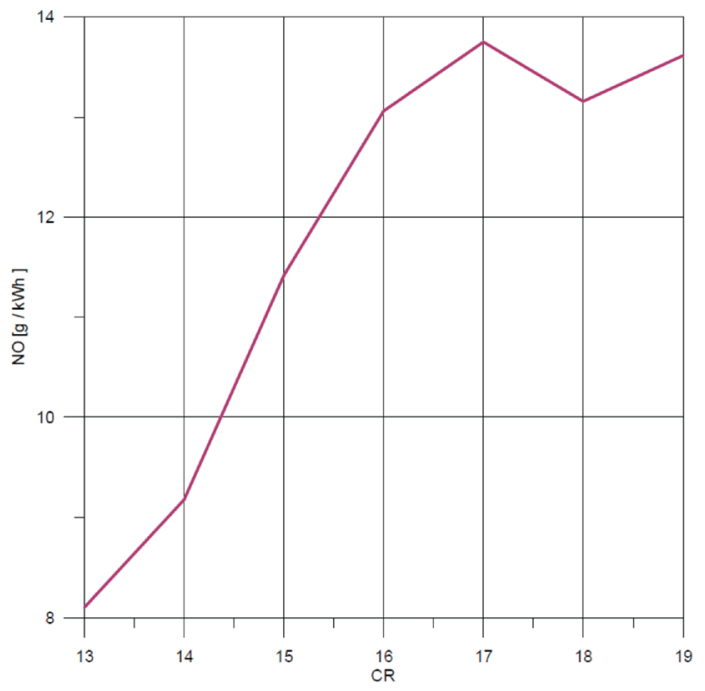

Fig. 6. Effect of compression ratio on nitric oxides $\mathrm{NO}_{x}$ specific emission (recalculated as NO emission) for variable compression ratio VCR engine

Rys. 6. Wplyw stopnia sprężania na emisję jednostkowa tlenków azotu NO (w przeliczeniu na NO) $w$ silniku o zmiennym stopniu sprężania VCR

nie jest zagadnieniem jednoznacznym. Gdy weźmie się pod uwagę pozytywny efekt energetyczny i ekologiczny w zakresie emisji cząstek stałych, optymalne wartości stopnia sprężania oscylują wokół liczby 16 . Takie wartości są z reguły standardowymi stopniami sprężania dla współ- 


\section{Problem synthesis based on the selected internal combustion engine layouts}

SkyActiv engines used in Mazda vehicles are examples of modern internal combustion engines where a constructional layout quite different from the current standards has been adopted, including the value of the compression ratio [8]. The characteristic feature of this family of engines is the value of the compression ratio set at 14.0, the same for both gasoline and diesel units. According to the manufacturer, these engines belong to the conceptually new system of components and powertrains of Mazda cars, designed in accordance with the idea of an innovative technology platform under the marketing name SkyActiv. They were introduced for the first time to the world markets in 2012 in the CX-5 and 6 car models. Among the wide range of engines especially interesting is the compression-ignition czesnych silników z zapłonem samoczynnym; gwarantują przy tym właściwe cechy eksploatacyjne silnika, jak np. łatwość i pewność rozruchu w niskich temperaturach. Jednak ze względu na istotny problem emisji tlenków azotu korzystniejsze byłyby niższe wartości stopnia sprężania, nawet $\varepsilon \leq 14$, co, jak pokaże dalsza analiza, wiąże się z koniecznością stosowania dodatkowych, zaawansowanych układów gwarantujących stabilną pracę silnika, zwłaszcza w fazie jego nagrzewania.

\section{Synteza problematyki na przykładzie wybranych konstrukcji silników spalinowych}

Przykładami nowoczesnych silników spalinowych, dla których przyjęto odbiegającą od obecnych standardów strategię założeń konstrukcyjnych, m.in. w zakresie stopnia sprężania, są silniki SkyActiv, stosowane w pojazdach marki

Table 1. Technical specifications of MAZDA 2.2 SKYACTIV-D engine [8]

Tabela 1. Charakterystyka techniczna silnika MAZDA 2.2 SKYACTIV-D [8]

\begin{tabular}{|c|c|}
\hline Engine type/rodzaj silnika & $\begin{array}{c}\text { direct injection compression-ignition, turbocharged/turbodoładowany, z zaplonem } \\
\text { samoczynnym i wtryskiem bezpośrednim }\end{array}$ \\
\hline Cylinder number and layout/liczba i uktad cylindrów & 4, inline/4 w uktadzie rzędowym \\
\hline Total engine capacity/pojemność skokowa & $2191 \mathrm{~cm}^{3}$ \\
\hline $\begin{array}{l}\text { Cylinder bore } \times \text { piston stroke/ } \\
\text { średnica cylindra } \times \text { skok ttoka }\end{array}$ & $86.0 \mathrm{~mm} \times 94.3 \mathrm{~mm}$ \\
\hline Compression ratio/stopień sprężania & 14.0 \\
\hline Max. power/moc maks. & 110 or $129 \mathrm{~kW}$ at $4500 \mathrm{rpm}$ \\
\hline Max. torque/maks. moment obrotowy & 380 or $420 \mathrm{~N} \cdot \mathrm{m}$ \\
\hline Valve layout/uktad rozrządu & DOHC, 4 valves per cylinder \\
\hline Valve train/napęd zaworów & $\begin{array}{l}\text { two overhead camshafts DOHC; main valve train with single row machine chain, mid- } \\
\text { camshaft train with two gears, fixed-phase inlet valves timing, two-phase exhaust valves } \\
\text { timing with on-demand opening of half number of valves during inlet stroke using triple } \\
\text { cams and switchable roller finger followers/dwa wałki krzywkowe zamontowane w głowicy } \\
\text { - układ DOHC; napęd jednego wałka łańcuchem maszynowym jednorzędowym od wału } \\
\text { korbowego, napęd międzywatkowy przekładnia zębata, stałe fazy rozrząu zaworów } \\
\text { ssacych, dwufazowy rozrząd zaworów wydechowych z aktywowana na żadanie faza } \\
\text { uchylenia połowy zaworów wydechowych w suwie ssania za pomoca potrójnych krzywek } \\
\text { i podwójnych, przełaczalnych dźwigni zaworowych }\end{array}$ \\
\hline Turbocharging system/system doładowania & $\begin{array}{c}\text { two turbochargers working together or separately, air cooling system intercooler/ } \\
\text { dwie turbosprężarki pracujace łacznie lub niezależie, układ chłodzenia powietrza } \\
\text { doładowujacego intercooler }\end{array}$ \\
\hline Fuel system/uktad zasilania & $\begin{array}{l}\text { DENSO common-rail, multihole piezoelectric injectors, splitting fuel dose up to } 9 \text { parts, } \\
\text { max. fuel injection pressure } 2000 \text { bar/DENSO typu common-rail, wtryskiwacze piezoele- } \\
\text { ktryczne wielootworkowe, umożliwiajace podziat dawki paliwa na } 9 \text { części, maksymalne } \\
\text { ciśnienie wtrysku paliwa } 2000 \text { bar }\end{array}$ \\
\hline $\begin{array}{l}\text { Exhaust aftertreatment system/system ograniczania } \\
\text { emisji spalin }\end{array}$ & $\begin{array}{l}\text { cooled exhaust gas recirculation EGR, oxidation catalyst and diesel particulate filter } \\
\text { periodically cleaned due to temperature increase through additional fuel injection during } \\
\text { exhaust stroke/układ recyrkulacji spalin EGR z chłodnica spalin, uktad wydechowy } \\
\text { z katalizatorem utleniajacym i filtrem czastek statych, okresowe oczyszczanie filtra czastek } \\
\text { statych metoda termiczna przez dodatkowy }\end{array}$ \\
\hline Exhaust emission standard/poziom emisji spalin & Euro 6 \\
\hline Lubrication system/uktad olejenia & $\begin{array}{l}\text { under circulation, full-flow oil filter, pressurized lubrication of crankshaft bearings, the } \\
\text { rest of pairs lubricated by oil splashing, cooling oil spray on the bottom of piston head/ } \\
\text { obiegowy, filtr petnego przeptywu, łożyska ślizgowe smarowane pod ciśnieniem, pozostate } \\
\text { pary trace smarowane rozbryzgowo, chłodzacy natrysk oleju pod denka tłoków }\end{array}$ \\
\hline - oil filter type/typ filtra oleju & $\begin{array}{l}\text { Mazda SHY1 } 14302 \text { - alternately also MAHLE OC1182, BluePrint ADM52123, WIX } \\
\text { WXWL7516, Filtron OP 597/1 }\end{array}$ \\
\hline $\begin{array}{l}\text { - recommended oil class and type/zalecany typ I klasa } \\
\text { oleju smarujacego }\end{array}$ & $\begin{array}{l}\text { Mazda Original Oil Supra DPF 0W-30 } \\
\text { Mazda Original Oil Ultra DPF 5W-30 }\end{array}$ \\
\hline
\end{tabular}


engine marked as SkyActiv-D. Its displacement is $2.2 \mathrm{~L}$ and maximum power is $129 \mathrm{~kW}$ at $4500 \mathrm{rpm}$. It is worth noting that despite the global trend towards "downsized" engines, the SkyActiv engines are developed according to different concepts involving, among others, on reducing the compression ratio of the engine. A more complete SkyActiv-D engine specification is given in Table 1 .

The relatively low for a compression ignition engine geometric compression ratio of 14.0 , allows for reduced mechanical loads of main parts of the engine structure, thus the engine block, for example, can be made of less strength but much lighter alloys. According to the manufacturer, the overall engine weight is decreased by about $25 \mathrm{~kg}$ compared to previous, similarly sized engines.

Another, yet definitely the most important benefit of lowered compression ratio is the reduction of nitrogen oxides $\mathrm{NO}_{\mathrm{x}}$ emissions. Thanks to low $\mathrm{CR}$ value, the engine can meet the current limits on nitrogen oxides emissions (Euro 6, for example) without the need to use the expensive and problematic aftertreatment systems in exhaust duct like selective reduction of nitrogen oxides SCR/AdBlue $\AA$. This gives it a significant advantage, mainly from the point of view of the end users.

Unfortunately, reducing the compression ratio in diesel engines too much brings many negative consequences. In order to compensate the drop in indicated efficiency of the work cycle, and to further ensure appropriate parameters for power, torque, and engine dynamics in a wide range of engine speeds and loads, it was necessary to supercharge the engine with an efficient and fast, low inertia device. Thus the SkyActiv-D engine is equipped with a pair of two turbochargers (Fig. 7), working together or independently.

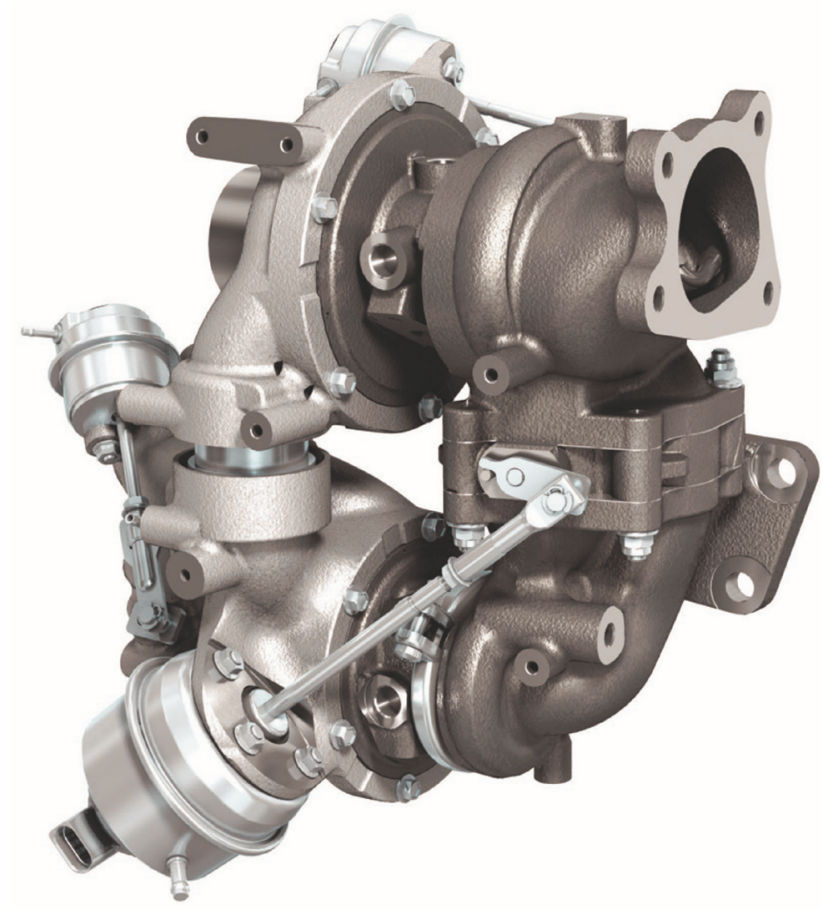

Fig. 7. Turbocharging unit of SkyActiv-D engine [4] Rys. 7. Zespót turbosprężarek silnika SkyActiv-D [4]
Mazda [8]. Ich cechą charakterystyczną jest wartość stopnia sprężania ustalona na poziomie $14 \mathrm{i}$ jest ona jednakowa zarówno dla jednostki napędowej z zapłonem iskrowym, jak i z zapłonem samoczynnym. Jak podaje producent, silniki te należą do koncepcyjnie nowego systemu podzespołów i układów funkcjonalnych samochodów marki Mazda, zaprojektowanych zgodnie z ideą innowacyjnej platformy technologicznej o marketingowej nazwie SkyActiv. Wprowadzone zostały po raz pierwszy na rynki światowe w $2012 \mathrm{r}$. w modelach CX-5, Mazda 6. Wśród szerokiej gamy jednostek napędowych na szczególną uwagę zasługuje wersja silnika z zapłonem samoczynnym, oznaczana jako SkyActiv-D, o pojemności skokowej 2,2 1 i mocy maksymalnej $129 \mathrm{~kW}$ przy $4500 \mathrm{obr} / \mathrm{min}$. Warto zaznaczyć, że pomimo ogólnoświatowego trendu w kierunku tzw. downsizingu, jednostki napędowe SkyActiv są rozwijane wg odmiennej koncepcji, polegającej m.in. na wyraźnym odprężeniu silnika. Pełniejszą charakterystykę techniczną silnika SkyAcyiv-D podano w tabeli 1.

Stosunkowo niski, jak na silnik z zapłonem samoczynnym, geometryczny stopień sprężania o wartości 14 pozwala na uzyskanie zredukowanych obciążeń mechanicznych elementów roboczych silnika, stąd np. kadłub silnika może być wykonany z mniej wytrzymałych, ale za to znacznie lżejszych stopów lekkich. Według informacji producenta, uzyskano zmniejszenie ogólnej masy silnika o około $25 \mathrm{~kg}$ w stosunku do poprzednich, porównywalnych konstrukcji.

Kolejną, najważniejszą korzyścią wynikającą z zastosowania zmniejszonego stopnia sprężania jest obniżenie emisji tlenków azotu $\mathrm{NO}_{x}$. Dzięki temu silnik może spełnić obecne limity emisji tlenków azotu (tj. na poziomie normy Euro 6) bez konieczności stosowania w układzie wydechowym kosztownego i problematycznego w eksploatacji systemu selektywnej redukcji tlenków azotu SCR/AdBlue ${ }^{\circledR}$, co jest istotną zaletą, chociażby z punktu widzenia użytkownika końcowego.

Radykalne obniżenie stopnia sprężania w silniku z zapłonem samoczynnym powoduje jednak wiele niekorzystnych konsekwencji. Celem zrekompensowania spadku sprawności indykowanej obiegu, a w dalszej konsekwencji dla zapewnienia właściwych parametrów mocy, momentu obrotowego, dynamiki silnika w szerokim zakresie prędkości obrotowej i zmian obciążenia itd., konieczne było zastosowanie wydajnego układu doładowania o małej bezwładności. Silnik SkyActiv-D wyposażono zatem w układ dwóch turbosprężarek (rys. 7), pracujących łącznie lub niezależnie.

Turbosprężarka o większej wydajności (a także bezwładności działania), uaktywniana jest przy większych obciążeniach; druga, o mniejszej wydajności, ale też o mniejszej bezwładności działania, pozwala na utrzymanie żądanego przebiegu momentu obrotowego przy nagłych zmianach obciążenia. Sterowanie włączaniem poszczególnych turbin i sprężarek odbywa się za pomocą sterowanych klap upustowych, zarówno po stronie spalin, jak i powietrza doładowującego (rys. 7).

Zastosowanie obniżonego stopnia sprężania powoduje znaczne zmniejszenie zdolności rozruchowych silnika oraz 
The turbocharger with a higher efficiency (and also with higher device inertia) is activated at higher loads; the second one with a lower efficiency, but also with lower device inertia, allows to maintain the desired rate of torque at quick load changes. Controlling the activation of individual turbines and compressors is done using controlled pressure relief valves on both the exhaust and supercharged air sides (Fig. 7).

The use of low compression ratio results in a significant deterioration in motor starting capability and leads to unstable operation due to ignitability problem, known as the "misfire" phenomenon, especially during start-up and initial phase of the engine warming up. Therefore, in order to make starting the SkyActiv-D engine easier, efficient ceramic glow plugs are placed directly in the combustion chamber and the appropriate fuel injection strategy is implemented as well.

To ensure the stability of the combustion process in the engine warm-up phase, an "on demand" control strategy for hot exhaust gas recirculation has also been applied. It is performed by a mechanical double lift of a half of exhaust valves system IDEVA. The function of double exhaust valve lift is achieved by a triple-cam of the camshaft and a switchable, double rocker arm (Fig. 8).

The first opening of the exhaust valves takes place normally during the exhaust stroke. The second opening a slight gap of one exhaust valve for each cylinder occurs during the intake stroke, and it is intended to provide the cylinders with a small portion of hot gases to raise the incylinder temperature assuring reliable self-ignition of the fuel (Fig. 9).

The single-alloy camshaft is made of ductile iron; cam surfaces are hardened through induction heating process. The sliding surfaces of rocker arms that co-work with prowadzi do niestabilnej pracy w postaci tzw. zjawiska wypadania zapłonów (ignitability problem), zwłaszcza podczas rozruchu i w początkowej fazie rozgrzewania się silnika. Aby zatem ułatwić rozruch w silniku SkyActiv-D zastosowano wydajne, ceramiczne świece żarowe umieszczone w komorze spalania oraz dostosowano odpowiednią strategię wtrysku paliwa.

Do zapewnienia stabilności procesu spalania w fazie nagrzewania się silnika zastosowano strategię sterowania "na żądanie" gorącą recyrkulacją spalin przez układ mechaniczny podwójnego wzniosu połowy zaworów wydechowych IDEVA. Funkcja podwójnego wzniosu zaworów wydechowych realizowana jest za pomocą potrójnych krzywek wałka rozrządu i przełączalnych, podwójnych dźwigni zaworowych (rys. 8).

Pierwsze otwarcie zaworów wydechowych standardowo występuje podczas suwu wydechu. Drugie, nieznaczne uchylenie jednego z zaworów wydechowych następuje w suwie ssania i ma na celu dostarczenie do cylindrów niewielkiej porcji gorących spalin, aby zwiększyć temperaturę ładunku do wartości zapewniającej pewny samozapłon paliwa (rys. 9).

Wałek rozrządu jednolity wykonany jest z żeliwa sferoidalnego; powierzchnia krzywek jest utwardzana indukcyjnie. Powierzchnie ślizgowe dźwigni zaworowych, współpracujące z zewnętrznymi krzywkami, z uwagi na duże naciski jednostkowe i występowanie tarcia ślizgowego są utwardzane azotkiem chromu w procesie cieplno-chemicznym, podczas którego wytwarzana jest bardzo twarda, lecz stosunkowo cienka warstwa ślizgowa o handlowej nazwie producenta dźwigienek zaworowych TriondurCN [11].

Złożoność konstrukcyjna, technologiczna i mechatroniczna układu rozrządu w silniku SkyActiv-D, choć godna uwagi, może w pewnych warunkach pracy silnika stwarzać określone problemy eksploatacyjne.

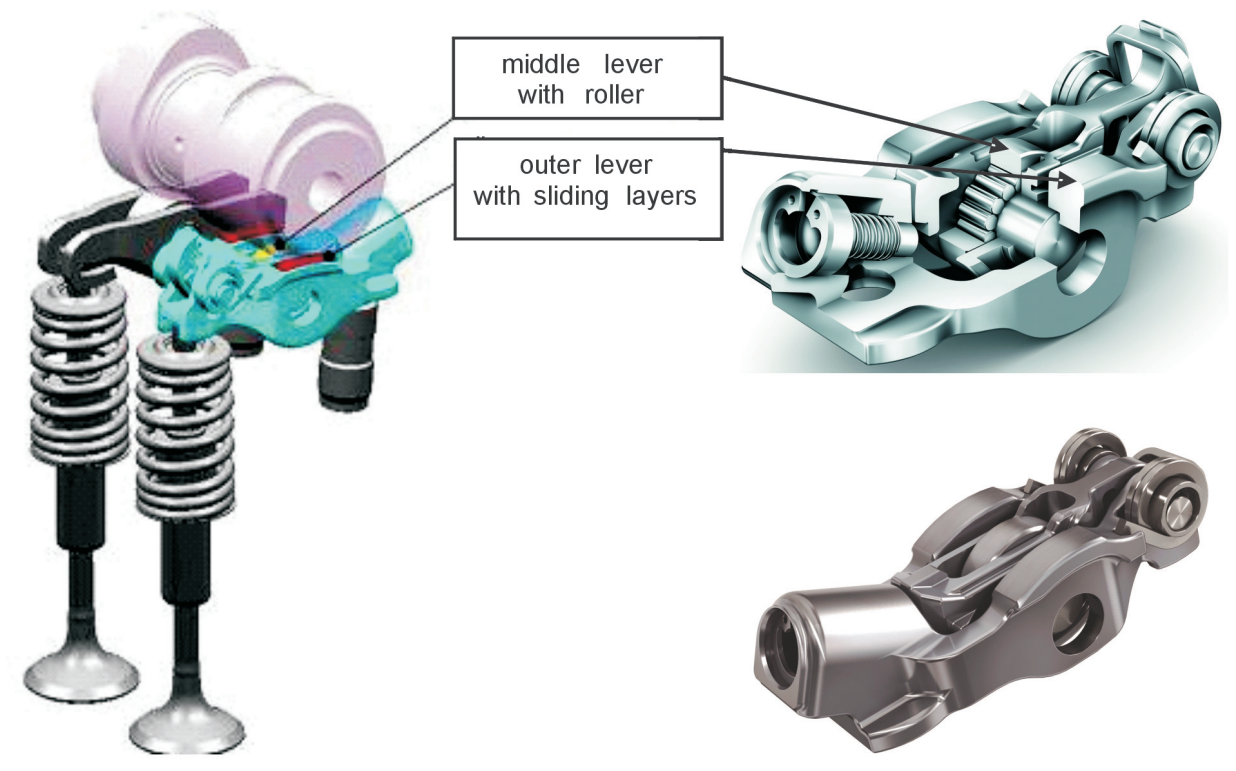

Fig. 8. Design of the two-phase exhaust valve lift system in the engine SkyActiv-D with "on-demand" hydro-electric switchable arms $[5,11]$

Rys. 8. Konstrukcja dwufazowego układu rozrządu zaworów wydechowych w silniku SkyActiv-D z elektrohydraulicznie przełączalnymi "na żądanie" dźwigienkami zaworowymi [5, 11]

\section{Podsumowanie}

Dobór konstrukcyjny optymalnej wartości stopnia sprężania jest zagadnieniem złożonym. Wybierając ustawienia odpowiednie pod względem przewidywanych parametrów użytecznych silnika, nie można zagwarantować właściwych wartości dla innych, istotnych np. z punktu widzenia ochrony środowiska naturalnego, parametrów roboczych i wyjściowych silnika. Pewne dodatkowe możliwości kompensacji niekorzystnych efektów, wynikających z założonych wartości 
outer cams, due to their operation under high unit pressure and sliding friction, are treated by chromium nitride in a thermo-chemical process, which creates a very hard but relatively thin sliding layer under the rocker manufacturer trade name TriondurCN [11].

The noteworthy complexity in design, technology, and mechatronics of SKYACTIV-D engine valve lifting system, may also cause specific technical problems under certain engine operating conditions.

\section{Conclusions}

Constructional selection of the optimum compression ratio value is a complex issue. Choosing the appropriate settings with regards to expected engine output parameters can not guarantee appropriate values for other parameters important from the point of view of environmental protection, engine operation and its output characteristics. Some possible compensation of adverse effects resulting from the fixed value of geometric compression ratio can be derived from simultaneously coupled extended control of supercharging, cold and hot exhaust gas recirculation, valve lifting and timing, and finally the use of complex maps of fuel injection characteristics and powerful functionality of individual engine components affecting engine working process. However, this results in a considerable growth in complexity of the engine working systems and its auxiliaries. A promising alternative, which might give many more advantages at simplifying the entire powerdrive system construction, is the still-under-development technology of variable compression ratio in VCR engines.

\section{Acknowledgements}

The authors wish to thank the authors of Diesel RK program from N.E. Bauman Moscow State Technical University for the opportunity to use their software in simulation tests.

\section{Podziękowania}

Autorzy artykułu dziękują autorom programu Diesel-RK z Moskiewskiego Państwowego Uniwersytetu Technicznego im. N. E. Baumana za możliwość wykorzystania ich oprogramowania w badaniach symulacyjnych.
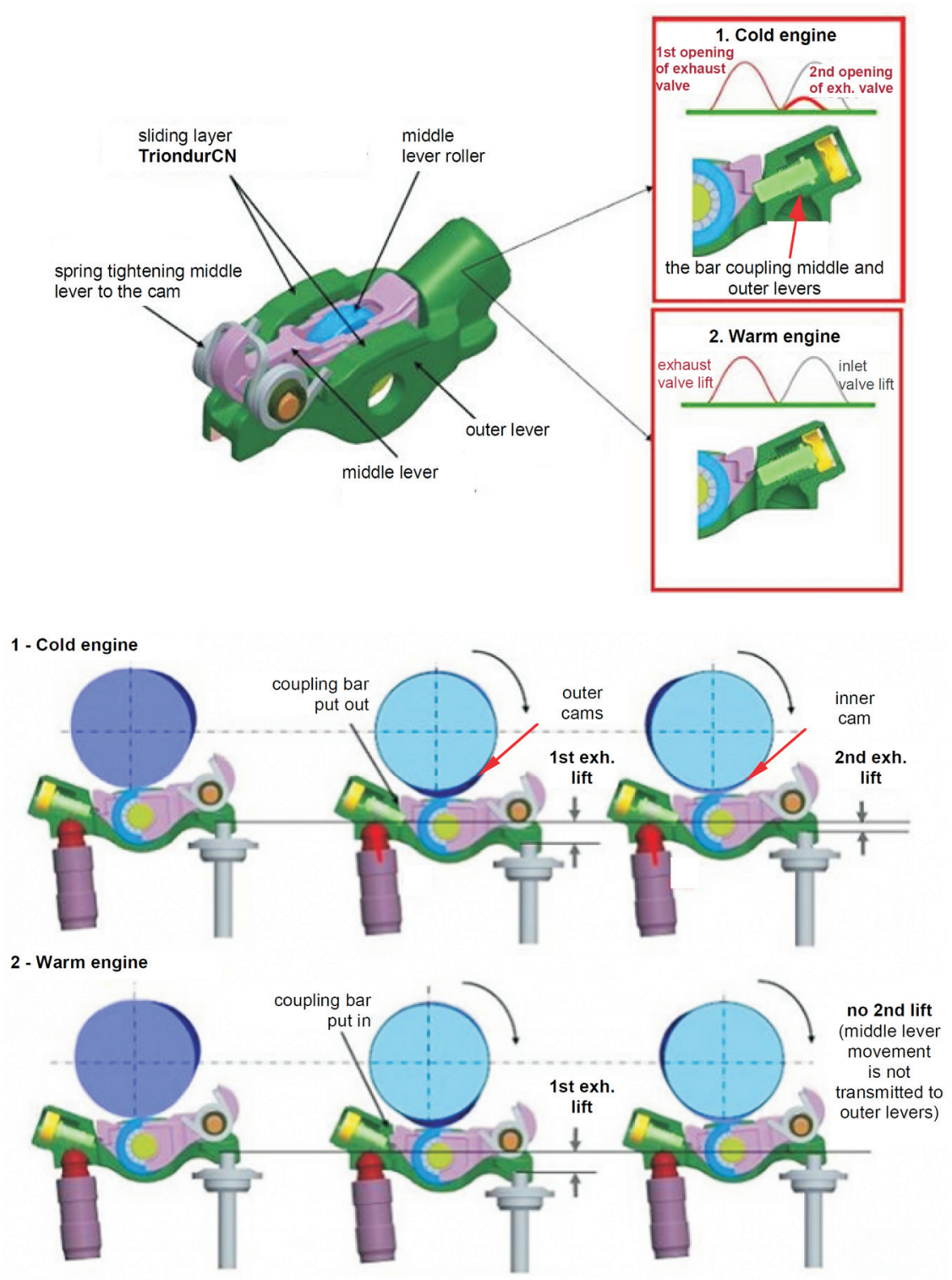

Fig. 9. Principle and operation modes of the two-phase exhaust valve lift system in the engine SkyActiv-D with "on-demand" hydro-electric switchable arms [5]

Rys. 9. Zasada i tryby działania dwufazowego układu rozrządu zaworów wydechowych w silniku SkyActiv-D z elektrohydraulicznie przełączalnymi "na żądanie" dźwigienkami zaworowymi [5]

geometrycznego stopnia sprężania, daje jednoczesne połączenie ze sobą rozszerzonego sterowania doładowaniem, chłodnej i gorącej recyrkulacji spalin, napędu zaworów, czy zastosowanie złożonych map sterowania wtryskiem paliwa i rozbudowanych funkcjonalności poszczególnych podzespołów mających wpływ na proces roboczy silnika. Wiąże się to jednak ze znacznym skomplikowaniem układów roboczych w silniku i jego osprzęcie. Obiecującą alternatywą, a mogącą dać znacznie więcej korzyści, przy jednoczesnym uproszczeniu konstrukcji całego układu napędowego, jest wciąż rozwijana technologia zmiennego stopnia sprężania w silnikach typu VCR. 


\section{Nomenclature/Skróty i oznaczenia}

MPI MultiPoint Injection/wtrysk wielopunktowy benzyny (pośredni)

GDI Gasoline Direct Injection/wtrysk bezpośredni benzyny

HCCI Homogenous Charge Compression Ignition/samozapłon ładunku homogenicznego

VCR Variable Compression Ratio/zmienny stopień sprężania

DI Direct Injection/wtrysk bezpośredni

CNG Compressed Natural Gas/sprężony gaz ziemny
LPG Liquified Petrolum Gas/gaz skroplony

CR Compression ratio/stopień sprężania

TDC/ZZ top dead center/zwrot zewnętrzny ttoka

$\mathrm{BDC} / \mathrm{ZW}$ bottom dead center/zwrot wewnętrzny tłoka

NO Nitrogen oxide/tlenek azotu

$\mathrm{NO}_{\mathrm{x}} \quad$ Nitrogen oxides/tlenki azotu

PM Particulatte matter/cząstki state

\section{Bibliography/Literatura}

[1] Abramek K.F. Zmiana stopnia sprężania i jej wpływ na właściwości rozruchowe silników z zapłonem samoczynnym. Zeszyty Naukowe Akademii Morskiej w Szczecinie, nr 10/2006.

[2] EUCAR R\&D for Europe, The European Council for Automotive R\&D Conference, 2006, www.eucar.be.

[3] Habermann K. Demonstration Vehicle with Continuously Variable Compression Ratio (VCR). FEV Magazine "Spectrum", Issue 22, 2003: www.fev.com.

[4] Hitomi M., Nakai E., Terazawa Y., Takamatsu H., Shimo D. Development of a New Generation Clean Diesel Engine (2.2L) which Achieves both Driving Pleasure and Environmental Performance - Realization of a concept for ultra-low compression ratio of 14.0. Mazda Motor Corporation, 2013.

[5] http://mechanical tech.jp/book/export/html/4810.

[6] Kuleshov A.S. Use of Multi-Zone DI Diesel Spray Combustion Model for Simulation and Optimization of Performance and Emissions of Engines with Multiple Injection. SAE Technical Paper No. 2006-01-1385, SAE International, Warrendale, PA, USA, 2006.

Paweł Woś, DEng. - Assistant Professor in the Faculty of Mechanical Engineering and Aeronautics at Rzeszów University of Technology.

Dr inż. Paweł Woś - adiunkt na Wydziale Budowy Maszyn i Lotnictwa Politechniki Rzeszowskiej. e-mail:pwos@prz.edu.pl

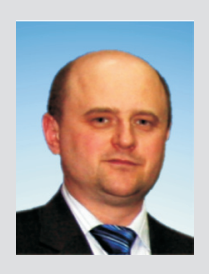

Hubert Kuszewski, DEng. - Assistant Professor in the Faculty of Mechanical Engineering and Aeronautics at Rzeszów University of Technology.

Dr inż. Hubert Kuszewski - adiunkt na Wydziale Budowy Maszyn i Lotnictwa Politechniki Rzeszowskiej.

e-mail:hkuszews@prz.edu.pl

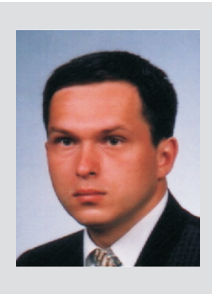

Adam Ustrzycki, DEng. - Assistant Professor in the Faculty of Mechanical Engineering and Aeronautics at Rzeszów University of Technology.

Dr inż. Adam Ustrzycki-adiunkt na Wydziale Budowy Maszyn i Lotnictwa Politechniki Rzeszowskiej. e-mail: austrzyc@prz.edu.pl
[7] Kuleshov A.S. Diesel-RK Engine Simulation Software User Manual. Moscow 2004.

[8] Mazda Motor Corporation Tech Newsletters: http://www. mazda.pl.

[9] MCE-5 Development Tech Newsletters: www.mce-5.com.

[10] Rault A. Mid and Long Term Powertrains Evolution. Presentation at EUCAR Conference, 2002.

[11] Scheidt M., Lang M. Pure Efficiency. Developing combusting engines from the perspective of a supplier. 10th Schaeffler Symposium, April 3/4-2014, Schaeffler Technologies AG \& Co. KG, 2014.

[12] Woś P., Balawender K., Jakubowski M., Kuszewski H., Lejda K., Ustrzycki A. Design of Affordable Multi-Cylinder Variable Compression Ratio (VCR) Engine for Advanced Combustion Research Purposes. SAE Technical Paper No. 2012-01-0414, SAE International, Warrendale, PA, USA, 2012.

[13] Woś P., Jakubowski M. Silnik tłokowy o zmiennym stopniu sprężania. Zgłoszenie patentowe nr P.389951 z dnia 18-122009 r. Biuletyn Urzędu Patentowego RP, nr 13/2011 (978), Warszawa 2011.

[14] Woś P. Procesy spalania niskotemperaturowego w silnikach tłokowych, [w:] Lejda K. (red.): Systemy i środki transportu samochodowego - wybrane zagadnienia. Seria: Transport, nr 3, Oficyna Wyd. Politechniki Rzeszowskiej, s. 229-234, Rzeszów 2012.

[15] Zabłocki M. Wtrysk i spalanie w silnikach wysokoprężnych. WKiŁ, Warszawa 1976.
Artur Jaworski, DEng. - Assistant Professor in the Faculty of Mechanical Engineering and Aeronautics at Rzeszów University of Technology.

Dr inż. Artur Jaworski-adiunkt na Wydziale Budowy Maszyn i Lotnictwa Politechniki Rzeszowskiej. e-mail: ajaworsk@prz.edu.pl

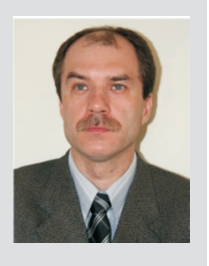

Prof. Kazimierz Lejda, DSc., DEng. - Professor in the Faculty of Mechanical Engineering and Aeronautics at Rzeszów University of Technology.

Prof. dr hab. inż. Kazimierz Lejda - profesor na Wydziale Budowy Maszyn i Lotnictwa Politechniki Rzeszowskiej.

e-mail:klejda@prz.edu.pl 